\title{
HUBUNGAN PENGETAHUAN DAN RIWAYAT PENYAKIT DENGAN KELAHIRAN PREMATUR DI RUMAHSAKIT UMUM DAERAH KOTA PADANGSIDIMPUAN
}

\author{
Wiwi Wardani Tanjung ${ }^{1}$, Ayu Ulfah Nur Lubis ${ }^{2, *}$, \\ ${ }^{1}$ Akademi Kebidanan Darmais Padangsidimpuanta, Indonesia \\ ${ }^{2,}$ STIKes Namira Madina Panyabungan, Indonesia \\ Email:*wiwiwardani85@gmail.com ${ }^{1}$, ayuulfahnurlubis@yahoo.com²
}

\begin{abstract}
Abstrak
World Health Organization (WHO) melaporkan setiap tahun 13 juta bayi lahir secara prematur di seluruh dunia dan satu juta bayi meninggal dunia. Hasil Riset Kesehatan Dasar (Riskesdas) tahun 2013 menunjukkan bahwa sebanyak 32,4\% kematian bayi usia 0-6 hari disebabkan oleh prematuritas. Kejadian prematur di RSUD Kota Padangsidimpuan terus meningkat dari tahun 2011-2014. Tujuan penelitian ini untuk mengetahui hubungan pengetahuan dan riwayat penyakit dengan kelahiran prematur di Rumah Sakit Umum Daerah Kota Padangsidimpuan. Jenis penelitian adalah studi analitik dengan pendekatan cross sectional. Populasi adalah seluruh ibu yang melahirkan prematur dan bukan prematur di RSUD Kota Padangsidimpuan. Sampel dalam penelitian ini adalah keseluruhan dari populasi yang berjumlah 92. Sampel dalam penelitian ini berjumlah 92 orang. Data dikumpulkan melalui rekam medik dan wawancara dengan menggunakan kuesioner. Data dianalisis secara univariat, bivariat dengan menggunakan uji Chi-Square pada taraf kepercayaan 95\% ( $\mathrm{P}<0,05)$. Hasil penelitian menunjukkan ada hubungan riwayat penyakit $(\mathrm{p}=0,0001)$ dengan kelahiran prematur, sedangkan variabel pengetahuan $(\mathrm{p}=0,061)$ tidak berhubungan terhadap kelahiran prematur. Disarankan kepada tenaga kesehatan untuk lebih mengoptimalkan pelayanan kesehatan dengan melakukan pemeriksaan antenatalcare sesuai dengan standar untuk mengetahui tekanan darah, kadar $\mathrm{Hb}$, glukosa darah dalam pencegahan preeklampsi, anemia, diabetes mellitus yang dapat berisiko terjadinya prematuritas. RSUD Kota Padangsidimpuan diharapkan meningkatkan konseling kesehatan kepada ibu tentang usia yang baik untuk hamil dan bersalin yaitu pada usia 20-34 tahun. Dinas kesehatan diharapkan melakukan bina suasana kepada kelompok masyarakat melalui perwiritan dalam mensosialisasikan tentang prematur
\end{abstract}

Kata kunci: Pengetahuan, Riwayat Penyakit, Prematur

\begin{abstract}
The World Health Organization (WHO) reports that every year 13 million babies are born prematurely worldwide and one million babies die. The results of the 2013 Basic Health Research (Riskesdas) showed that 32.4\% of infant deaths aged 0-6 days were caused by prematurity. Premature incidence in Padangsidimpuan City Hospital continues to increase from 2011-2014. The purpose of this study was to determine the relationship between knowledge and history of disease with premature birth at the Padangsidimpuan City General Hospital. This type of research is an analytic study with a cross sectional approach. The population was all mothers who gave birth prematurely and not prematurely at the Padangsidimpuan City Hospital. The sample in this study was the entire population of 92 people. The sample in this study amounted to 92 people. Data were collected through medical records and interviews using a questionnaire. Data were analyzed by univariate, bivariate using Chi-Square test at 95\% confidence level $(P<$ $0.05)$. The results showed that there was a relationship between medical history $(p=0.0001)$ and preterm birth, while the knowledge variable $(p=0.061)$ was not related to preterm birth. It is
\end{abstract}




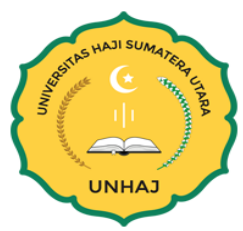

recommended for health workers to further optimize health services by conducting antenatal care examinations according to standards to determine blood pressure, Hb levels, blood glucose in the prevention of preeclampsia, anemia, diabetes mellitus which can be at risk of prematurity. Padangsidimpuan City Hospital is expected to improve health counseling to mothers about a good age for pregnancy and childbirth, namely at the age of 20-34 years. The health office is expected to develop an atmosphere for community groups through perwiritan in socializing about prematurity

Keywords: Maternal Factor, Premature Delivery

\section{Pendahuluan}

Persalinan preterm (prematur) merupakan persalinan yang berlangsung pada u $\mathrm{m}$ u r kehamilan 20-37 minggu dihitung dari hari pertama haid terakhir. Mortalitas dan morbiditas neonatus pada bayi prematur masih sangat tinggi.Hal ini berkaitan dengan maturitas organ pada bayi lahir seperti paru, otak dan gastrointestinal. Di Negar a Barat sampai $80 \%$ dari kematian neonatus adalah akibat prematuritas dan pada bayi yang selamat $10 \%$ mengalami permasalahan dalam jangka panjang (Prawiharjo, 2012).

World Health Organization (WHO) bekerja sama dengan March of Dimes, lembaga sosial dari Amerika Serikat yang memiliki misi mencegah bayi lahir prematur dan cacat melaporkan setiap tahun diperkirakan 13 juta bayi lahir secara prematur di seluruh dunia dan satu juta bayi meninggal dunia. Angka Kematian Bayi (AKB) menurut SDKI 2012 adalah 32 per 1.000 kelahiran hidup, 60\% bayi mati terjadi pada umur 1 bulan. Target Millenium Development Goals sampai dengan tahun 2015 adalah mengurangi angka kematian bayi dan balita sebes ar dua pertiga dari tahun 1990 men jadi 23 kematian per 1000 kelahiran di tahun 2015. Penyebab kematian bayi terse but an tara lain karena infeksi, asfiksia neonatorum, trauma kelahiran, cacat bawaan dan prematuritas. (Judarwanto, 2012; SDKI, 2012)

Berdasarkan hasil Riset Kesehatan Das ar (Riskesdas) tahun 2013 men un juk kan bahwa penyebab kematian terbanyak pada kelompok bayi 0-6 hari didominasi oleh gangguan/kelainan pernafasan $(35,9 \%)$, prematuritas $(32,4 \%)$ dan sepsis $(12 \%)$. Dew asa ini Indonesia memiliki angka kejadian prematur sekitar $19 \%$ dan merupak an pen yeb ab utama kematian perinatal. Hasil Riskesdas tahun 2013 menyatakan bahwa persentase prematuritas di Indonesia sebesar 10,2\% dan di Sumatera Utara sebesar 7,2\%.

Dampak yang ditimbulkan dari persalinan prematur cukup serius.Bayi dapat memiliki gangguan fisik maupun intelektualnya, gangguan respirasi, anoksia 12 kali lebih sering terjadi pada bayi preterm dibandingkan pada bayi aterm. Jika berat b ay i kurang dari 1000 gram, maka angka kematian naik menjadi 74\%. Perdarahan intrak ran ial lima kali lebih sering pada bayi preterm dibanding pada bayi aterm. (Edrin, 2012)

Hasil penelitian lain yang dilakukan oleh Baurlina tentang pengaruh fak tor ibu terhadap kejadian prematur ditemukan bahwa variabel penelitianyaitu paritas dan riwayat obstetri berpengaruh $(\mathrm{p}<0,05)$ terhadap persalinan prematur.

Prematuritas merupakan salah satu penyebab mortalitas dan morbiditas neonates.Kejadian prematur di Kota Padangsidimpuan terus mengalami peningkatan setiap tahunnya. Berdasarkan data yang diperoleh dari Rumah Sakit Umum Daerah Kota Padangsidimpuan diperoleh jumlah bayi prematur tahun 2011 sebanyak 40 orang, tahu n 2012 sebanyak 52 orang sedangkan tahun 2013 sebanyak 65 o rang dan pada tahun 2014 sebanyak 92 orang dari 889 kelahiran hidup. Dari studi pendahuluan yang telah dilakukan oleh peneliti didapatkan keseluruhan bayi yang lahir prematur di RSUD Kota Padangsidimpuan tahun 2014 adalah 92 (10,3\%) orang dari seluruh kel ahiran hidup. 
Diperkirakan $10 \%$ dari seluruh bayi baru lahir yang dirawat di Ruang Perinatologi disebabkan oleh prematuritas.

Berdasarkan uraian tersebut, maka rumusan masalah dalam penelitian ini adalah menganalisis pengaruh faktor ibu (umur, paritas, pen getahuan, riwayat ANC, riwayat penyakit ibu dan riwayat obstetri) terhadap kelahiran prematur di Rum ah Sakit Umu m Daerah Kota Padangsidimpuan"

Tujuan penelitian adalah untuk mengetahui hubungan pengetahuan dan riwayat penyakit dengan kelahiran prematur di Rumah Sakit Umum Daerah Kota Padangsidimpuan.

\section{Metode Penelitian}

Desain penelitian yang digunakan adalah penelitian kuantitatif dengan pendekatan cross sectional. Penelitian ini dilaksanakan di Rumah Sakit Umum Daerah Kota Padangsidimpuan. Populasi dalam penelitian ini berjumlah 92 orang. Sampel pada penelitian ini berjumlah 92 sampel. Data yang digunakan adalah data primer dan data sekunder Data dianalisis dengan uji Chi Square pada taraf kepercayaan 95\% $(\mathrm{P}<0,05)$.

\section{Hasil dan Pembahasan}

Hasil penelitian diperoleh responden sebanyak 92 orang, 46 kas us dan 46 kontrol, dengan persentase tertinggi responden pada kelompok kasus yang paling b an yak ad ala $\mathrm{h}$ umur $<20$ dan $\geq 35$ tahun sebanyak 30 responden $(65,2 \%)$ dan kelompok kontrol yang paling banyak adalah umur 20-34 tahun sebanyak 38 (82,6\%). Berdasarkan suku re spon den pada kelompok kasus yang paling banyak adalah batak sebanyak 37 responden $(80,4 \%)$ d an dan pada kelompok kontrol yang paling banyak adalah batak sebanyak 40 respo nden $(87,0 \%)$. Berdas arkan agama responden pada kelompok kasus yang paling banyak adalah agama Islam sebanyak 44 responden $(95,7 \%)$ dan pada kelompok kontrol yang paling bany ak adalah agama Islam sebany ak 39 responden $(84,8 \%)$

Tabel 1. Hubungan Pengetahuan dan Riwayat Penyakit dengan Kelahiran Prematur

\begin{tabular}{|c|c|c|c|c|c|c|}
\hline \multirow{3}{*}{ Variabel } & \multicolumn{4}{|c|}{ Kelompok } & \multirow{3}{*}{$\mathbf{P}$} & \multirow{3}{*}{$\begin{array}{c}\text { OR } \\
(95 \% \mathrm{Cl})\end{array}$} \\
\hline & \multicolumn{2}{|c|}{ Prematur } & \multicolumn{2}{|c|}{$\begin{array}{c}\text { Tidak } \\
\text { Prematur }\end{array}$} & & \\
\hline & n & $\%$ & $\mathbf{n}$ & $\%$ & & \\
\hline \multicolumn{7}{|l|}{ Pengetahuan } \\
\hline Baik & 19 & 20,7 & 28 & 30,4 & \multirow{3}{*}{0,061} & \multirow{3}{*}{$\begin{array}{c}2,211 \\
(0.960-5,088)\end{array}$} \\
\hline Tidak baik & 27 & 29,3 & 18 & 19,6 & & \\
\hline Riwayat Pen & & & & & & \\
\hline Ya & 37 & 40,2 & 13 & 14,1 & \multirow{2}{*}{0,0001} & \multirow{2}{*}{$\begin{array}{c}3,083 \\
(1,482-6,412)\end{array}$} \\
\hline Tidak & 9 & 9,8 & 33 & 35,9 & & \\
\hline
\end{tabular}

\section{Hubungan Pengetahuan terhadap Kelahiran Prematur}

Hasil penelitian menunjukkan bahwa pengetahuan ibu tidak berhubungan kelahiran prematur di Rumah Sakit Umum Daerah Kota Padangsidimpuan. Rendahnya 
pengetahuan ibu bersalin ini dikarenakan banyak yang tidak tahu pengertian, pencegahan dari prematur sampai penanganannya.

Pengetahuan merupakan hasil dari tahu setelah adanya penginderaan terh adap suatu objek dan sangat penting dalam pembentukan tindakan seseorang. Penelitian Rogers yang dikutip oleh Notoatmodjo mengungkapkan apabila penerimaan perilaku baru atau adopsi perilaku melalui proses seperti ini yang didasari o leh pengetahuan, kesadaran dan sikap yang positif (long lasting). Sebaliknya apabila perilaku itu tidak didasari oleh pengetahuan dan kesadaran maka tidak akan berlangs ung lama (Notoadmodjo, 2012)

Hasil penelitian ini sejalan dengan hasil penelitian Baurlina (2012) yang menyatakan bahwa proporsi ibu yang pengetahuannya buruk lebih banyak pada kelompok kasus yaitu sebanyak $66,2 \%$ dan pada kelompok kontrol yang pengetahuannya kurang sebanyak 58,4\%. Analisis pengaruh antara pengetahuan terhadap kelahiran prematur dengan nilai OR sebesar 1,40 dengan $95 \% \mathrm{CI}=0,73-2,68$ dan nilai $\mathrm{p}=0,318$ artinya tidak ada pengaruh pengetahu an terhadap persalinan prematur.

Menurut peneliti, jika dilihat dari jawaban pengetahuan responden tentang prematur masih kurang. Hal ini dapat dilihat dari beberapa reponden yang tidak mengetahui bahwa kelahiran bayi prematur dapat dicegah dengan melakukan kunjun gan kehamilan secara teraturyaitu sebany ak 52,2\%, namun secara statistik pengetahuan tidak memengaruhi terhadap kelahiran prematur. Hal ini karena penyebab kelahiran prematurdi Rumah Sakit Umum Daerah Kota Padangsidimpuan, berhubungan lan gs ung dengan kehamilan ibu seperti usia ibu yang terlalu muda ataupun terlalu tua, riwayat penyakit dan obstetri yang dimiliki ibu.

\section{Hubungan Riwayat Penyakit dengan Kelahiran Prematur}

Hasil penelitian menunjukkan bahwariwayat penyakit ibu berhubungan kelahiran prematur di Rumah Sakit Umum Daerah Kota Padangsidimpuan. Penyakit yang dialami ibu memengaruhi kondisi kesehatan ibu hamil dan sangat berpengaruh kepada pertumbuhan dan perkembangan bayi yang dapat menyebabkan kelahiran prematur.

Hasil penelitian juga menunjukkan bahwa ibu yang melahirkan prematur memiliki riwayat penyakitjantung sebesar $10,9 \%$. Kehamilan terdapat peningkatan denyu t jan tu ng ibu untuk mengimbangi pertumbuhan dan perkembangan janin dalam rahim dan dapat menyebabkan terjadinya keguguran, persalinan prematur

Riwayat penyakit DM yang dimiliki ibu yang melahirkan pre matur sebesar $13 \%$. Diabetes Mellitus (DM) adalah penyakit kelainan metabolisme dimana tubuh pend erita tidak bisa secara otomatis mengendalikan tingkat gula (glukosa) dalam darahnya. (Maryunani, 2013)

Pada ibu hamil dengan DM yang tidak diobati pada waktu kehamilan ju ga dapat menimbulkan risiko terjadinya penyulit pada kehamilan berupa pre-eklampsi, lahir prematur, kelainan letak pada janin, cairan ketuban yang berlebihan (hidramnion) dan infeksi pada saluran kemih. (Rukiyah, 2010)

Hasil penelitian ini sejalan dengan hasil penelitian Baurlina (2012) yang menyatakan ada pengaruh riwayat penyakit terhadap persalinan prematur. Hal ini sejalan dengan penelitian yang dilakukan oleh Rahmawati yang menyatakan bahwa riwayat penyakit anemia berhubungan dengan persalinan preterm dengan nilai $\mathrm{p}=0,001$. (Rahmawati, 2013) 


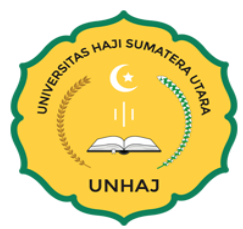

\section{Kesimpulan}

Berdasarkan hasil penelitian, maka kesimpulan yang dapat diperoleh yaitu variabel pengethauan tidak berhubungan dengan kelahiran prematur sedangkan riway at penyakit dan berhubungan dengan kelahiran prematur di Rumah Sakit Umum Daerah Kota Padangsidimpuan.

\section{Referensi}

Baurlina. Karakteristik Ibu yang Melahirkan Bayi Prematur Di RSUD Kota Padangsidimpuan [Tesis]. Medan: Program Studi Ilmu Kesehatan Masyarakat, Universitas Sumatera Utara; 2012.

Edrin VL. Gambaran karakteristik ibu hamil pada persalinan prematurdi RSUP Dr. M. Djamil [dokumen di internet]. 2012. Tersedia dari:http://fk.unand.ac.id/index.php/jka/article/download/ 110/105.

Judarwanto. Angka kejadian kelahiran prematur di Indonesia dan Dunia . [d oku men di internet]. 2012. Tersedia dari: http://prematurenicu. wordpress.com/2012/12/08

Kemenkes RI. Riset kesehatan dasar 2013. Jakarta: Kementerian Kesehatan Republik Indonesia; 2014.

Maryunani A.Asuhan kegawatdaruratan maternal dan neonatal. Jakarta: CV Trans In fo Media; 2013.

Notoatmodjo. Promosi kesehatan dan perilaku kesehatan. Jakarta: Rineka Cipta; 2012

Prawiharjo S. Ilmu kebidanan. Jakarta: Yayasan Bina Pustaka; 2012.

Rahmawati D. Faktor-faktor yang memengaruhi terjadinya persalinan preterm [Skripsi]. Surakarta: Fakultas Ilmu Kesehatan Universitas Muhammadiyah; 2013.

Rukiyah AY. Asuhan kebidanan IV (patologi kebidanan). Jakarta: CV.Trans Info Media; 2010.

SDKI. Laporan pendahuluan bidang pusat statistik. Jakarta: Badan Kepend ud uk an dan Keluarga Berencana Nasional Kementerian Kesehatan. Jakarta; 2012.

WHO.World health report [dokumen di internet]. 2010. Tersedia dari: http://www.who.int/whr/2010/annex/annexes 3-4en.pdf 